\title{
Response of Teff (Eragrostis tef (Zucc) Trotter) to Seeding Rate and Methods of Sowing on Yield and Yield Attributes in a Subhumid Environment, Northern Ethiopia
}

\author{
Abraha Arefaine, Daniel Adhanom $(\mathbb{D}$, and Negasi Tekeste \\ Aksum University, Shire Campus, Department of Plant Sciences, P.O.Box 314, Shire, Ethiopia \\ Correspondence should be addressed to Daniel Adhanom; danieladhanom@gmail.com
}

Received 8 October 2019; Revised 22 June 2020; Accepted 13 July 2020; Published 3 August 2020

Academic Editor: Kent Burkey

Copyright (c) 2020 Abraha Arefaine et al. This is an open access article distributed under the Creative Commons Attribution License, which permits unrestricted use, distribution, and reproduction in any medium, provided the original work is properly cited.

\begin{abstract}
Teff is a dominantly cultivated and stable crop in Ethiopia primarily grown for its grain which is used for preparing injera. In spite of its importance, the productivity is very low due to many factors among them, and poor agronomic practices are the major ones. In view of this, a field experiment, under rain-fed condition, was conducted at Laelay Machew district with the objective of evaluating the response of teff to seeding rate and methods of sowing during 2017/18 main cropping season. The experiment comprised four levels of seeding rate $(10,15,20$, and $25 \mathrm{~kg} / \mathrm{ha}$ ) and two methods of sowing (broad casting and row planting), and the experiment was laid in a $2 \times 4$ factorial arrangement in randomized complete block design (RCBD), replicated three times. Data related to phenology, growth, yield, and yield attributes were collected and analyzed using SAS software. Results indicated that days to panicle emergence, plant height, total number of tillers, productive tillers, main panicle seed weight, thousand-seed weight, panicle length, and harvest index were significantly $(P<0.05)$ affected by the main effects of seeding rate and methods of sowing but these parameters showed no response to interaction effects of the two treatment factors. However, the interaction of the two treatment factors affected grain yield, biological yield, and straw yield. Plots sown with low seeding rate $(10 \mathrm{~kg} / \mathrm{ha})$ combined with row planting gave high grain yield $(2333 \mathrm{~kg} / \mathrm{ha})$, biological yield $(7666 \mathrm{~kg} / \mathrm{ha})$, and straw yield $(5333 \mathrm{~kg} / \mathrm{ha})$. Therefore, using treatment combinations of seeding rate of $10 \mathrm{~kg} \cdot \mathrm{ha}^{-1}$ together with the row method of sowing can be advised for teff production in the subhumid areas of central zone of Tigray.
\end{abstract}

\section{Introduction}

Teff is one of the most important cereal crops and Ethiopia is considered as the origin and diversity of the crop [1]. Teff is highly adapted to diverse agro ecological zones including marginal areas where most crops cannot be properly grown [2]. Even though it is small seeded crop, Ethiopian farmers prefer to grow teff because of its multiple advantages such as high market value, reduced postharvest management cost, and low risk, and the straw is preferable as animal feed compared with other cereal crops [3].

Teff is primarily grown for its grain used for preparing injera, which is a staple and very popular food in the national diet of most Ethiopians. It can also be used as other food products such as kitta (unleavened bread), anebaberro (double-layered injera), porridge, gruel, and local alcoholic beverages such as tella and katikala $[4,5]$.

Teff accounts for about $22.6 \%$ of the total area and $16 \%$ of the gross grain production of the major cereals cultivated in Ethiopia [6]. The area devoted to teff cultivation is large as compared to other major cereals crops. Teff production and demand has been increasing from year to year in both rural and urban areas of Ethiopia [7]. Despite the aforementioned importance and large area coverage, its productivity is very low with a national average yield of $1.56 t \cdot \mathrm{ha}^{-1}$ [8]. This low yield is mainly attributed to lack of appropriate method of sowing and optimum seeding rate [9].

Seed rate is one of the important factors in achieving optimum level of plant density and has considerable effects on growth and development of crops $[5,10]$. It also greatly 
affects productivity of crops when combined with sowing method. In the study area, there is inconsistency in using improved cultural practices like seeding rate and method of sowing and results in low yield teff. The most common method of sowing is broadcasting which is traditional and greatly reduces the amount of teff grain yield due to higher competition for resources and also lodging [11]. On the other hand, row planting maintains uniform population per unit area and provides easy access for carrying out cultural practices although requires more time, energy, and cost [12]. However, in the study area, there was lack of information on the response of teff crop to seeding rate and methods of sowing. Thus, boosting the productivity of teff through improved agronomic practices especially seeding rate and methods of sowing are highly required. Therefore, the research was initiated with the overall objective of evaluating the growth and yield response of teff to seeding rate and methods of sowing in subhumid environment of Laelay Maychew district.

\section{Materials and Methods}

2.1. Description of the Study Area. The study was conducted at Laelay Maychew district (Hatsebo site) central zones of Tigray region, northern Ethiopia. The area is known for its potential for teff production in the region. The experimental site located at $5 \mathrm{~km}$ East of Axum town situated at $38^{\circ} 34^{\prime}$ and $39^{\circ} 25^{\prime}$ East longitude and $13^{\circ} 15^{\prime}$ and $14^{\circ} 39^{\prime}$ North latitude. The soil texture of the experimental area is clay loam and a soil type of vertisols [13]. The study area is classified as subhumid agroecology where most of the middle altitude crops such as teff, wheat, and Faba bean are commonly grown. The average rainfall and temperature are $720 \mathrm{~mm}$ and $19^{\circ} \mathrm{C}$ per annum, respectively. The area is characterized by unimodal rainfall pattern, which starts in June and extends up to September.

2.2. Treatments and Experimental Design. The two factors tested were seeding rate with four levels $(10,15,20$, and $25 \mathrm{~kg} \cdot \mathrm{ha} / \mathrm{ha}$ ) and two methods of sowing (broadcasting and row). There was a total of eight treatment combinations and the experiment followed a $2 \times 4$ factorial arrangement in a randomized complete block design (RCBD) replicated three times. The seeds were either drilled in specified rows or broad casted by spreading on the plots. In the row sowing method, each plot contained 10 rows spaced at $20 \mathrm{~cm}$. All plots were $2 \mathrm{~m} \times 2 \mathrm{~m}\left(4 \mathrm{~m}^{2}\right)$ with $1 \mathrm{~m}$ distance between plots in a block and $1.5 \mathrm{~m}$ between blocks. In the experiment, a dominantly cultivated Quncho variety of teff was used as a test crop.

2.3. Agronomic Practices. The experimental site was ploughed by oxen 4 times before final preparation of seed beds. Urea $(46 \% \mathrm{~N})$ at a rate of $100 \mathrm{~kg} \cdot \mathrm{ha}^{-1}$ and NPS $(19 \% \mathrm{~N}$, $38 \% \mathrm{P}, 7 \% \mathrm{~S}$ ) fertilizer at $100 \mathrm{~kg} \cdot \mathrm{ha}^{-1}$ were used as a source of nitrogen, phosphorus, and sulfur. Full dose of NPS was applied at the time of sowing, while urea fertilizer was applied in two equal splits, the first portion 15 days after planting and the remaining amount being top dressed at tillering stage. Weed control was managed by hand weeding without herbicides.

\subsection{Data Collection}

2.4.1. Phenological Data. Days to 50\% panicle emergence were recorded by counting the number of days after planting when $50 \%$ of the teff crop in a plot started panicle emergence. Days to $90 \%$ physiological maturity were determined as the number of days from sowing to the time when $90 \%$ of plants in a plot reached maturity based on leaf senescence as well as release of grain from the glumes when manually threshed by pressing between the forefinger and thumb. Lodging index was also measured visually at harvesting time of each plot through displacement of the aerial parts of the plants in percent determined by the angle of inclination of the main stem from the vertical line to the base of the stem and the degree of lodging was assessed based on the scales of 0-5 recorded at GS-55 and GS-73 according to the formula developed by [14].

2.4.2. Growth, Yield, and Yield Components. Panicle length, plant height, total tillers, productive tillers, main panicle seed weight, thousand-seed weight, grain yield, biological yield, straw yield, and harvest index were recorded. Panicle length was recorded by measuring the length of the panicle from the node where the first panicle branch starts to the tip of the panicle in centimeter at their physiological maturity and the average of ten randomly selected plants in a plot was used for statistical analysis. Plant height was measured in centimeter from the base of the main stem to the tip of the panicle at physiological maturity from ten randomly selected plants. Total and productive tillers were also measured as the total numbers of productive and nonproductive tillers were counted at physiological maturity from each plot to determine total as well as productive tillers from ten randomly selected plants.

Thousand-seed weight was measured as the weight of 1000 seeds in grams after harvesting and measured using a sensitive balance. Grain yield was recorded as the weight of the teff grain yield per plot after air drying for ten days to about $12 \%$ moisture content following harvest and measured using a sensitive balance expressed in grams and then converted into kilograms per hectare. Biological yield was recorded by weighing the whole plant parts, from the net plot area at maturity, just after drying for 10 days and measured using a sensitive balance and expressed in kilograms per hectare. From the aboveground dry biomass, the grain yield was subtracted to record the straw yield. Finally, harvest index was calculated by dividing grain yield to the total biological yield.

2.5. Data Analysis. Data collected were subjected to analysis of variance using SAS Statistical software version 9.1.3 [15]. Means were separated using Fisher's LSD at 5\% probability level. Data for lodging percentage were transformed by using 
arcsine method. Pearson's correlation analysis was also carried out to assess the relationship between different parameters.

\section{Results and Discussion}

\subsection{Crop Phenology}

3.1.1. Days to 50\% Panicle Emergence, Days to 90\% Physiological Maturity, and Lodging Index. Days to 50\% panicle emergence was significantly $(P<0.05)$ affected by the main effect of seeding rate and methods of sowing (Table 1), while days to $90 \%$ physiological maturity and lodging index were only affected by the main effect of seeding rate. However, these parameters showed no response to interactions effect of the two treatment factors (Table 1).

Maximum number of days to $50 \%$ panicle emergence was recorded at plots treated with seeding rate of $10 \mathrm{~kg} / \mathrm{ha}$ which took 52 days but was not significantly different with days recorded from $15 \mathrm{~kg} / \mathrm{ha}$ seeding rate. However, $25 \mathrm{~kg} /$ ha seed rate took shorter time of 48 days for $50 \%$ panicle emergence even though statistically at par with plots received seeding rate of $20 \mathrm{~kg} / \mathrm{ha}$ (Table 1 ). This result is in line with the finding of [11] who reported that plants treated with high seeding rate flowered earlier than plants grown under low seed rate.

Plots sown using broadcasting method of sowing produced panicle earlier than those tef seeds sown using row method of sowing. Teff seeds sown in row delayed the time to $50 \%$ panicle emergence by about 1.5 days compared to the broadcasted treatments (Table 1). This might be due to seeds sown in row; there would be effective use and less competition for the limited resource available which allows the plants to stay more time in a vegetative growth instead to early heading. This result is similar with [16] that found the number of days required for panicle emergence increased as seeding rated increased but contrary to the finding in [17] who reported row planted teff flowered earlier than broadcasted ones.

The highest days to physiological maturity (93) and lodging index were observed from the low seeding rate $(10 \mathrm{~kg} / \mathrm{ha})$ although at par with seeding rate of $15 \mathrm{~kg} / \mathrm{ha}$ (Table 1). Plots treated with the lowest seeding rate of $10 \mathrm{~kg} /$ ha reached physiological maturity lately. However, plots sown at seeding rate of $25 \mathrm{~kg} / \mathrm{ha}$ reached physiological maturity 7 days earlier than the plots sown with the lowest seeding rate. This might be due to resource competition at higher seeding rate which finally led to dry and reach maturity earlier. This result is in line with the findings in [17] who reported a delay in days to maturity with a decrease in seed rate. The lowest seeding rate revealed high lodging index (47). This could be due to the plots sown with the lowest seeding rate produced high panicle length, main panicle seed weight, thousand-seed weight, and high grain yield exert a strain on the stalk and led to fall down especially under high wind or wind driven rain. This result is in contrast with findings in $[17,18]$ on which high lodging index observed from high seeding rate (25 kg/ha).

\subsection{Growth, Yield, and Yield Components}

3.2.1. Plant Height, Panicle Length, Total Tillers, Productive Tillers, and Main Panicle Seed Weight. Seeding rate and methods of sowing significantly $(P<0.05)$ influenced plant height, panicle length, main panicle seed weight, total, and productive tillers but the interaction of the two treatment factors did not affect the parameters (Table 2).

Tallest plant height $(118.8 \mathrm{~cm})$ was obtained at seeding rate of $15 \mathrm{~kg} / \mathrm{ha}$ which was statistically similar to plant height obtained at seeding rate of $10 \mathrm{~kg} / \mathrm{ha}$. However, the minimum plant height $(111.7 \mathrm{~cm})$ was recorded from the higher seeding rate of $25 \mathrm{~kg} / \mathrm{ha}$ and was not statistically different from $20 \mathrm{~kg} /$ ha seeding rate of plant height ( Table 2). This might be due to high competition between plants for growth resources which led to less vegetative growth and plant height. Similarly, [18] reported that plant height increased as seeding rate decreased. Taller and more branched plants were observed at the lower plant densities of sesame [19]. However, contradicting findings were reported by [17] who found a tallest plant height with higher seeding rate of $25 \mathrm{~kg} / \mathrm{ha}$.

Seeds sown using row method gave $4 \%$ taller plant height $(117.9 \mathrm{~cm})$ than sown using broadcasting. This might be due to less intraspecific competition of plants for light and nutrients as well as soil moisture which allows for increased vegetative growth. Similar findings were reported by other researchers who showed that an increase in plant height with row method of sowing and lower seeding rate [20]. Likewise, the authors of [21] revealed that the maximum plant height in wheat was obtained from row planting method.

As the seeding rate increased from 10 to $25 \mathrm{~kg} / \mathrm{ha}$ and panicle length decreased by $8 \%$ which was positively correlated with grain yield.

The increased panicle length from the combination of row sowing and reduced seeding rate might be the result of more space provided for the crop to utilize more growth resources by decreasing competition among plants. This finding is similar with [9] who reported that significantly higher panicle length was observed under low seeding rate than in high seeding rate.

Seeds sown using the row method of sowing produced taller panicle length $(49 \mathrm{~cm})$, while broad casted seeds gave shorter panicle length $(44 \mathrm{~cm})$ (Table 2$)$. This could be due to less competition in row sown teff. Similarly, the authors of [22] indicated increment in panicle length with row method of sowing as compared to broadcast sowing method.

The lowest seeding rate revealed the highest number of total tillers, productive tillers, and main panicle seed weight. The maximum number of total tillers (7.2 plant $\left.^{-1}\right)$, productive tillers (6.6 plant $\left.^{-1}\right)$, and main panicle seed weight $(9.2 \mathrm{~g})$ were obtained at lower seeding rate of $10 \mathrm{~kg} / \mathrm{ha}$. However, the minimum number of total tillers (3.5/plant), productive tillers (3.2/plant), and main panicle seed weight was recorded from the highest seeding rate $(25 \mathrm{~kg} / \mathrm{ha})$ and was statistically on par with a seeding rate of $20 \mathrm{~kg} / \mathrm{ha}$ (Table 2). This was similar to [23] who revealed that as the population density increased, competition for resource also increased, resulting in less tillering. This finding was also in 
TABLE 1: Main effect of the seeding rate and methods of sowing on days to $50 \%$ panicle emergence, days to $90 \%$ physiological maturity, and lodging index of teff crop.

\begin{tabular}{|c|c|c|c|}
\hline Treatments & Days to $50 \%$ panicle emergence & Days to $90 \%$ physiological maturity & Lodging index \\
\hline \multicolumn{4}{|c|}{ Seeding rate $(\mathrm{kg} / \mathrm{ha})$} \\
\hline 10 & $51^{\mathrm{a}}$ & $93^{\mathrm{a}}$ & $47^{\mathrm{a}}$ \\
\hline 15 & $50^{\mathrm{ab}}$ & $89^{\mathrm{ab}}$ & $44^{\mathrm{ab}}$ \\
\hline 20 & $48^{\mathrm{bc}}$ & $87^{\mathrm{b}}$ & $39^{\mathrm{b}}$ \\
\hline 25 & $47^{\mathrm{c}}$ & $86^{\mathrm{b}}$ & $39^{\mathrm{b}}$ \\
\hline LSD $(0.05)$ & 2 & 5 & 8 \\
\hline \multicolumn{4}{|c|}{ Methods of sowing } \\
\hline Broad casting & $48^{\mathrm{b}}$ & 88 & 42 \\
\hline Row & $50^{\mathrm{a}}$ & 90 & 43 \\
\hline LSD (0.05) & 1.6 & NS & NS \\
\hline CV (\%) & 3.63 & 4.22 & 14.51 \\
\hline
\end{tabular}

Means with the same superscript letter within a column do not statistically differ at 0.05 probability level according to Fisher's LSD.

TABLE 2: Main effect of the seed rate and method of sowing on plant height, panicle length, total tillers, productive tillers, main panicle seed weight, and harvest index of teff.

\begin{tabular}{|c|c|c|c|c|c|c|c|}
\hline Treatments & $\begin{array}{c}\text { Plant } \\
\text { height }(\mathrm{cm})\end{array}$ & $\begin{array}{c}\text { Panicle } \\
\text { length }(\mathrm{cm})\end{array}$ & $\begin{array}{c}\text { Total tillers } \\
\text { plant }^{-1}\end{array}$ & $\begin{array}{c}\text { Productive tillers } \\
\text { plant }^{-1}\end{array}$ & $\begin{array}{c}\text { Main panicle } \\
\text { seed weight }(\mathrm{g})\end{array}$ & $\begin{array}{c}\text { Harvest } \\
\text { index (\%) }\end{array}$ & $\begin{array}{c}\text { Thousand-seed } \\
\text { weight }(\mathrm{g})\end{array}$ \\
\hline \multicolumn{8}{|c|}{ Seeding rate $(\mathrm{kg} / \mathrm{ha})$} \\
\hline 10 & $118.6^{\mathrm{a}}$ & $48.7^{\mathrm{a}}$ & $7.2^{\mathrm{a}}$ & $6.6^{\mathrm{a}}$ & $9.2^{\mathrm{a}}$ & $27.2^{\mathrm{a}}$ & $0.3233^{\mathrm{a}}$ \\
\hline 15 & $118.8^{\mathrm{a}}$ & $46.9^{\mathrm{ab}}$ & $4.8^{\mathrm{b}}$ & $4.5^{\mathrm{b}}$ & $7.5^{b}$ & $20.8^{\mathrm{b}}$ & $0.2983^{\mathrm{ab}}$ \\
\hline 20 & $113.4^{\mathrm{b}}$ & $46^{\mathrm{b}}$ & $4.4^{\mathrm{c}}$ & $3.9^{c}$ & $7.2^{\mathrm{bc}}$ & $23.7^{\mathrm{ab}}$ & $0.2700^{\mathrm{bc}}$ \\
\hline 25 & $111.7^{\mathrm{b}}$ & $45^{\mathrm{b}}$ & $3.5^{\mathrm{c}}$ & $3.2^{\mathrm{c}}$ & $5.8^{\mathrm{c}}$ & $23.1^{\mathrm{b}}$ & $0.2566^{\mathrm{c}}$ \\
\hline LSD (0.05) & 3.8 & 2.7 & 1.11 & 0.96 & 1.4 & 3.8 & 0.037 \\
\hline \multicolumn{8}{|c|}{ Methods of sowing } \\
\hline Broadcasting & $113.3^{\mathrm{b}}$ & $44.3^{\mathrm{b}}$ & $3.9^{\mathrm{b}}$ & $3.5^{\mathrm{b}}$ & $6.7^{\mathrm{b}}$ & $21.6^{\mathrm{b}}$ & $0.263^{\mathrm{b}}$ \\
\hline Row & $117.9^{\mathrm{a}}$ & $49.0^{\mathrm{a}}$ & $6.1^{\mathrm{a}}$ & $5.7^{\mathrm{a}}$ & $8.2^{\mathrm{a}}$ & $25.8^{\mathrm{a}}$ & $0.311^{\mathrm{a}}$ \\
\hline LSD (0.05) & 2.7 & 1.9 & 0.79 & 0.68 & 1.00 & 0.027 & 0.0261 \\
\hline $\mathrm{CV}(\%)$ & 2.63 & 4.59 & 17.99 & 17.00 & 15.43 & 12.86 & 10.40 \\
\hline
\end{tabular}

Means with the same superscript letter within a column do not differ significantly at 0.05 probability level according to Fisher's LSD.

line with [24] who reported that as seeding rate increased, the numbers of total and productive tillers decreased.

Teff planted in row also showed high total tillers, productive tillers, and main panicle seed weight as compared to broadcasting method. Crops with higher number of effective tillers could have higher grain yield, straw yield, and biomass yield.

3.2.2. Grain Yield, Biological Yield, and Straw Yield. Grain yield, biological yield, and straw yield were significantly $(P<0.05)$ affected by the main effect of seeding rate and method of sowing as well as by the interaction of both treatment factors (Tables 3-5).

The highest grain yield $(2333 \mathrm{~kg} / \mathrm{ha})$ was obtained from the lower seeding rate of $10 \mathrm{~kg} / \mathrm{ha}$ combined with row sowing method. There was about $94 \%$ increment in grain yield of teff recorded at lower seeding rate of $10 \mathrm{~kg} / \mathrm{ha}$ sown in row method over the highest seeding rate sown in row method of sowing. The maximum yield obtained from lower seeding rate combined with row planting might be due to the combined effects of row sowing method that facilitated better field management and lower seeding rate that contributed to lesser plant population by minimizing intraspecific competition for growth resources among plants. This result is similar to [22] who reported the combination of row sowing method and lower seeding rate gave the highest grain yield of teff. Similarly, [7] also revealed that there was significant increase in yield and yield components of teff with decreased seeding rate from the highest to the lowest.

The maximum biological yield $(7667 \mathrm{~kg} / \mathrm{ha})$ was obtained from the lowest seeding rate $(10 \mathrm{~kg} / \mathrm{ha})$ planted in row while the minimum biological yield ( $4500 \mathrm{~kg} / \mathrm{ha}$ ) was recorded from the seeding rate of $20 \mathrm{~kg} / \mathrm{ha}$ sown using broadcasting method but was not statistically different with plots sown with the seeding rate of $25 \mathrm{~kg} / \mathrm{ha}$. Thus, the maximum biological yield which was obtained from $10 \mathrm{~kg} /$ ha seeding rate exceeded the minimum biological yield by about $70 \%$. This might be due to increased grain yield and the straw of the crop. In contrast to this result, [7] found total above-ground biomass increment with an increase in seeding rate and nitrogen fertilizer of teff.

With regard to straw yield of teff, there was a similar trend with the biological yield where the maximum straw yield ( $5333 \mathrm{~kg} / \mathrm{ha}$ ) was obtained from the lowest seeding rate planted in row but it was statistically similar with the straw yield obtained from $15 \mathrm{~kg} / \mathrm{ha}$ sown in both methods of sowing as well as with that of $20 \mathrm{~kg} /$ ha sown in row planting method (Table 5). However, the lowest straw yield $(3500 \mathrm{~kg} /$ ha) was recorded at $20 \mathrm{~kg} /$ ha seeding rate combined with broadcasting method of sowing (Table 5). 
TABLE 3: Interaction and main effect of seeding rate and methods of sowing on grain yield of teff $(\mathrm{kg} / \mathrm{ha})$.

\begin{tabular}{|c|c|c|c|c|c|}
\hline \multirow{2}{*}{ Methods of sowing } & \multicolumn{5}{|c|}{ Seeding rate $(\mathrm{kg} / \mathrm{ha})$} \\
\hline & 10 & 15 & 20 & 25 & Main effect \\
\hline Broad casting & $1167^{\mathrm{bc}}$ & $1050^{\mathrm{bc}}$ & $1000^{c}$ & $1000^{c}$ & $1054^{\mathrm{b}}$ \\
\hline Row & $2333^{\mathrm{a}}$ & $1500^{\mathrm{b}}$ & $1417^{\mathrm{bc}}$ & $1200^{\mathrm{bc}}$ & $1613^{\mathrm{a}}$ \\
\hline \multirow[t]{2}{*}{ Main effect } & $1750^{\mathrm{a}}$ & $1275^{\mathrm{b}}$ & $1208^{\mathrm{b}}$ & $1100^{\mathrm{b}}$ & \\
\hline & Interaction & Seeding rate & & & Method of sowing \\
\hline LSD (5\%) & 456 & 322 & & & 228 \\
\hline CV (\%) & 19.53 & & & & \\
\hline
\end{tabular}

Means with the same superscript letter within a column do not statistically differ at 0.05 probability level according to Fisher's LSD.

TABLE 4: Interaction and main effect of seeding rate and methods of sowing on biological yield teff (kg/ha).

\begin{tabular}{lccccc}
\hline \multirow{2}{*}{ Methods of sowing } & \multicolumn{3}{c}{ Seeding rate (kg/ha) } \\
& 10 & 15 & 20 & 25 & Main effect \\
\hline Broadcasting & $4833^{\mathrm{cd}}$ & $5900^{\mathrm{bc}}$ & $4500^{\mathrm{d}}$ & $4767^{\mathrm{cd}}$ & $5000^{\mathrm{b}}$ \\
Row & $7667^{\mathrm{a}}$ & $6333^{\mathrm{b}}$ & $5833^{\mathrm{bc}}$ & $4767^{\mathrm{cd}}$ & $6150^{\mathrm{a}}$ \\
Main effect & $6250^{\mathrm{a}}$ & $6117^{\mathrm{a}}$ & $5167^{\mathrm{b}}$ & $4767^{\mathrm{b}}$ & Methods of sowing \\
LSD (5\%) & Interaction & Seeding rate & & 643 \\
CV (\%) & 1286 & 909 & & \\
\hline
\end{tabular}

Means with the same superscript letter within a column do not statistically differ at 0.05 probability level according to Fisher's LSD.

TABLE 5: Interaction and main effect of seeding rate and methods of sowing on straw yield of teff (kg/ha).

\begin{tabular}{|c|c|c|c|c|c|}
\hline \multirow{2}{*}{ Methods of sowing } & \multicolumn{5}{|c|}{ Seeding rate $(\mathrm{kg} / \mathrm{ha})$} \\
\hline & 10 & 15 & 20 & 25 & Main effect \\
\hline Broadcasting & $3667^{\mathrm{b}}$ & $4850^{\mathrm{a}}$ & $3500^{\mathrm{b}}$ & $3767^{b}$ & $3946^{\mathrm{b}}$ \\
\hline Row & $5333^{\mathrm{a}}$ & $4833^{\mathrm{a}}$ & $4417^{\mathrm{ab}}$ & $3567^{\mathrm{b}}$ & $4538^{\mathrm{a}}$ \\
\hline \multirow[t]{2}{*}{ Main effect } & $4500^{\mathrm{ab}}$ & $4841^{\mathrm{a}}$ & $3958^{\mathrm{bc}}$ & $3667^{\mathrm{c}}$ & \\
\hline & Interaction & Seeding rate & & & Methods of sowing \\
\hline LSD $(5 \%)$ & 985 & 697 & & & 493 \\
\hline $\mathrm{CV}(\%)$ & 13.26 & & & & \\
\hline
\end{tabular}

Means with the same superscript letter within a column do not statistically differ at 0.05 probability level according to Fisher's LSD.

In general, high straw yield was obtained from low seeding rate sown in rows compared to the broadcasting method as the result of better field management of crops might have favored the stem to accumulate more dry matter. Similar finding was also reported by Melaku [7] that straw yield is significantly affected by main effect of seeding and $\mathrm{N}$ rates.

\subsubsection{Thousand-Seed Weight and Harvest Index.} Analysis of variance showed that thousand-seed weight and harvest index were significantly $(P<0.05)$ affected by the main effect of the two treatment factors (Table 2) while their interactions showed no response to the parameters. The heaviest thousand-seed weight $(0.32 \mathrm{~g})$ was recorded at the lowest seeding rate of $10 \mathrm{~kg} / \mathrm{ha}$ despite being statistically nonsignificant with $15 \mathrm{~kg} / \mathrm{ha}$ seed rate which gave $0.29 \mathrm{~g}$. However, the lowest thousand-seed weight was $0.26 \mathrm{~g}$ at seeding rate of $25 \mathrm{~kg} / \mathrm{ha}$. In general, as seeding rate decreased, thousand-seed weight increased and this might be because lower seeding rate enhances efficiently utilization of the existing resources and thus improves vegetative as well as reproductive growth. Similar finding was reported by [25] who revealed a higher thousand-seed weight with decreasing seeding rate which is due to vigorous crop growth compared to reduced thousand-seed weight and final yield at a higher seeding rate.

Thousand-seed weight was also influenced by the methods of sowing where plants sown in rows produced higher thousand-seed weight than the broadcast method. Moreover, seeds planted in row method of sowing showed $18 \%$ increase in thousand-seed weight over broadcasting (Table 2). This might be due to increased seed content and weight as a result of efficient resource utilization.

The highest harvest index (27.2\%) was obtained from the lowest seeding rate $(10 \mathrm{~kg} / \mathrm{ha})$ despite being statistically similar with seeding rate of $20 \mathrm{~kg} /$ ha (Table 2). The higher harvest index obtained in the lowest seeding rate can be attributed to more light penetration through plant canopy and improved nutrient supply. This finding was in agreement with the results by [26] who revealed that, at high density, carbohydrate supply was limited because of shading among plants and the competition between shoot growth and panicle growth.

Maximum harvest index $(25.8 \%)$ was also found when seeds were sown in rows as compared with broadcasting. This might be due to better growth in row sowing, less weed competition, and easy utilization of the existing resource (nutrient, sunlight, and water). 
TABLE 6: Pearson's correlation.

\begin{tabular}{|c|c|c|c|c|c|c|c|c|c|c|c|c|}
\hline & FPPaE & NiPPhM & PanL & PLH & TT & PROTi & MPSW & ThouSW & Gy & BioY & StY & $\mathrm{HI}$ \\
\hline FPPaE & - & & & & & & & & & & & \\
\hline NiPPhM & $0.891^{* * *}$ & - & & & & & & & & & & \\
\hline PanL & $0.624^{* *}$ & $0.545^{* *}$ & - & & & & & & & & & \\
\hline PLH & $0.420^{*}$ & $0.351 \mathrm{~ns}$ & $0.593^{* *}$ & - & & & & & & & & \\
\hline TT & $0.640^{* * *}$ & $0.688^{* * *}$ & $0.70^{* * *}$ & $0.673^{* * *}$ & - & & & & & & & \\
\hline PROTi & $0.689^{* * *}$ & $0.723^{* * *}$ & $0.751^{* * *}$ & $0.646^{* * *}$ & $0.969^{* * *}$ & - & & & & & & \\
\hline MPSW & $0.589^{* *}$ & $0.536^{* *}$ & $0.729^{* * *}$ & $0.551^{* *}$ & $0.736^{* * *}$ & $0.783^{* * *}$ & - & & & & & \\
\hline ThouSW & $0.466^{*}$ & $0.556^{* *}$ & $0.604^{* *}$ & $0.564^{* *}$ & $0.716^{* * *}$ & $0.786^{* * *}$ & $0.720^{* * *}$ & - & & & & \\
\hline Gy & $0.632^{* * *}$ & $0.729^{* * *}$ & $0.690^{* * *}$ & $0.473^{*}$ & $0.816^{* * *}$ & $0.840^{* * *}$ & $0.798^{* * *}$ & $0.787^{* * *}$ & - & & & \\
\hline BioY & $0.647^{* * *}$ & $0.685^{* * *}$ & $0.662^{* * *}$ & $0.0004^{*}$ & $0.674^{* * *}$ & $0.720^{* * *}$ & $0.743^{* * *}$ & $0.784^{* * *}$ & $0.843^{* * *}$ & - & & \\
\hline StY & $0.561^{* *}$ & $0.559^{* *}$ & $0.549^{* *}$ & $0.352 \mathrm{~ns}$ & $0.491^{*}$ & $0.544^{* *}$ & $0.603^{* *}$ & $0.668^{* * *}$ & $0.627^{* * *}$ & $0.947^{* * *}$ & - & \\
\hline $\mathrm{HI}$ & $0.405^{*}$ & $0.531^{* *}$ & $0.490^{*}$ & $0.354 \mathrm{~ns}$ & $0.663^{* * *}$ & $0.651^{* * *}$ & $0.561^{* *}$ & $0.511^{*}$ & $0.816^{* * *}$ & $0.386 \mathrm{~ns}$ & $0.074 \mathrm{~ns}$ & - \\
\hline
\end{tabular}

$\mathrm{FPPaE}=$ fifty percent panicle emergence, $\mathrm{NiPPhM}=$ minty percent physiological maturity, $\mathrm{PanL}=$ panicle length, $\mathrm{PLH}=$ plant height, TT $=$ total tiller, $\mathrm{PROTi}=$ productive tiller, MPSW $=$ main panicle seed weight, ThouSW $=$ thousand-seed weight, $\mathrm{Gy}=$ grain yield, BioY $=$ biological yield, $\mathrm{StY}=$ straw yield, $\mathrm{HI}=$ harvest index, and $\mathrm{ns}=$ nonsignificant. ${ }^{*}$ indicates probability at $5 \%,{ }^{* *}$ indicates probability at $1 \%$ and ${ }^{* * *}$ indicates probability at $0.1^{*}$.

3.3. Pearson's Correlation between Growth, Yield, and Yield Components. Table 6 indicates that teff grain yield was highly significantly $(P<0.05)$ and positively correlated with all phenological, growth, yield, and yield components of teff. Days to panicle emergence $\left(0.632^{* * *}\right)$ and days to physiological maturity $\left(0.729^{* * *}\right)$, panicle length $\left(0.690^{* * *}\right)$, plant height $\left(0.473^{*}\right)$, total number of tillers $\left(0.816^{* * *}\right)$, number of productive tillers $\left(0.840^{* * *}\right)$, main panicle seed weight $\left(0.798^{* * *}\right)$, thousand-seed weight $\left(0.787^{* * *}\right)$, biological yield $\left(0.843^{* * *}\right)$, straw yield $\left(0.627^{* *}\right)$, and harvest index $\left(0.816^{* * *}\right)$. Similar findings were reported by [27] where grain yield was significantly and positively correlated with thousand-seed weight, plant height, and biomass yield of wheat. The authors in [28] indicated a significant and positive correlation between grain yield and shoot biomass. Straw yield of teff had significantly $(P \leq 0.001)$ and positively correlated with all parameters except plant height $\left(0.352^{\mathrm{ns}}\right)$ and harvest index $\left(0.074^{\mathrm{ns}}\right)$ (Table 6). Moreover, a significant $(P \leq 0.05)$ and positive correlation was observed between straw yield and grain yield of wheat [26].

\section{Conclusion and Recommendation}

Days to panicle emergence, lodging percentage, plant height, physiological maturity, total tillers, productive tillers, thousand-seed weight, main panicle seed weight, harvest index, and panicle length were not affected by the interaction effect of seeding rate and methods of sowing. However, the interaction of the two factors significantly affected grain yield, biological yield, and straw yield.

The highest productive tillers and main panicle seed weight were recorded from the lowest seeding rate. As the seeding rate increased, these parameters decreased. The productive tillers which were obtained from the highest seeding rate were decreased by $100 \%$ as the seed rate decreased to $10 \mathrm{~kg} / \mathrm{ha}$. Almost all parameters were significantly affected by the main effect of method of sowing.

In the study area, farmers used $25 \mathrm{~kg} /$ ha seeding rate but based on the study the highest yield and yield components obtained from the lowest seeding rate $(10 \mathrm{~kg} / \mathrm{ha})$. Using high seed rate not only reduces yield but also increases the cost of the seed for the farmer.

In general, plots sown with low seeding rate combined with row planting method produced the highest grain yield, biological yield, and straw yield. Therefore, a seeding rate of $10 \mathrm{~kg} /$ ha combined with row planting method is recommended for the farmers in the study area.

\section{Data Availability}

The data used to support the findings of this study are available from the corresponding author upon request.

\section{Conflicts of Interest}

The authors declare that they have no conflicts of interest.

\section{Acknowledgments}

The authors first would like to thank Aksum University for providing financial support for conducting the research. The authors would also like to express their appreciation to plant science department for providing them the necessary materials for carrying out the research. The authors also thank Agriculture and Rural Development office, Laelay Maychew district, for facilitating experimental area for conducting the research.

\section{References}

[1] N. I. Vavilov, "The origin, variation, immunity and breeding of cultivated plants," Chronica Botanica, vol. 13, pp. 1-351, 1951.

[2] H. Tefera and S. Ketema, "2001 Production and importance of tef [Eragrostis tef (Zucc) Trotter] in Ethiopian agriculture," in Proceedings of the Tef research and development proceeding of the International work shop on tef genetics and improvement, Debre Zeit, Ethiopia, October 2000.

[3] S. Ketema, Germplasm Evaluation and Breeding Work on Tef in Ethiopia, Cambridge University Press, Cambridge, UK, 1991.

[4] W. Asrat and F. Tekabe, "Utilization of tef in the Ethiopian diet," in Proceedings of the Narrowing the Rift:Tef Research and 
Development, Proceedings of the International Workshop on tef Genetics and Improvement, pp. 239-244, Addis Ababa, Ethiopia, October 2000.

[5] S. Ketema, "Phenotypic variations in tef (Eragrostis tef) germplasm- morphological and agronomic traits. A catalog," Technical manual No. 6, Institute of Agricultural Research, Addis Ababa, Ethiopia, 1993.

[6] CSA (Central Statistic Authority), Agricultural Sample Survey: Report on Area and Production of Major Crops (Private Peasant Holdings “meher" Season), Vol. I, CSA, Addis Abeba, Ethiopia, 2012.

[7] M. Melaku, "Effects of seeding and nitrogen rates on yield and yield components of tef [Eragrostis tef (Zucc.) at Adet, Northern western Ethiopia," M.Sc. Thesis, Haramaya University, Dire Dawa, Ethiopia, 2008.

[8] CSA (Central Statistic Authority), Agricultural Sample Survey: Report on Area and Production of Major Crops (Private Peasant Holdings "meher" Season), Vol. I, CSA, Addis Abeba, Ethiopia, 2016.

[9] T. Berhe, "Increasing Productivity of Tef, Eragrostis Tef (Zucc.) Trotter: New Approaches with Dramatic Results (Unpublished Report)" Addis Ababa, Ethiopia, 2008.

[10] K. D. Kurubetta, "Effect of time of sowing, spacing and seed rate on seed production potentiality and quality of fodder cowpea [vigna unguiculata (L.) walp]," Msc. Thesis, College Of Agriculture, Dharwad University of Agricultural Sciences, Dharwad, India, 2006.

[11] W. Tesfahun, "Tef yield response to NPS fertilizer and methods of sowing in east shewa, Ethiopia," The Journal of Agricultural Sciences, vol. 13, no. 2, pp. 162-171, 2018.

[12] B. K. A. Chandrasekaran and E. Somasundaram, A Text Book of Agronomy, New Age International Limited Publisher, New Delhi, India, 2010.

[13] B. Tewolde, G. Gebreyohannes, and K. Abrha, "Validation of blended NPSB fertilizer on yield and yield componenst of teff (eragrostis tef (zuccagani) trotter) on vertisols on centeral Tigray Ethiopia," in Proceeding of national work shop: the role of blended in enhancing productivity and quality of crops in Ethipoa, 07-08, 2019, Tigray Agricultural Research Institute and Agricultural Growth Program-II, Mekelle, Ethiopia, 2019.

[14] D. W. L. Read and F. G. Worder, "Wheat and barley response to rates of seeding and fertilizer in southern Sasketchewan," Agronomy Journal, vol. 74, pp. 33-36, 1981.

[15] SAS, SAS/STAT User's Guide, SAS institute Inc., Cary, NC, USA, 2002.

[16] R. Abraham, N. Dechassa, and K. Assefa, "Evaluation of seed rates and sowing methods on growth, yield and yield attributes of tef [Eragrostis tef (Zucc.) Trotter] in Ada District, East Shewa, Ethiopia," Biology, Agriculture and Healthcare, vol. 4, no. 23, 2014.

[17] B. Abebe and T. Workayehu, "Effect of method of sowing on yield and yield components of tef (eragrostis tef (zucc) trotter) at shebedino," Southern Ethiopia Global Journal of Chemistry, vol. 2, no. 1, 2015.

[18] S. Sahle and T. Altaye, "Effects of sowing methods and seed rates on yield components and yield of tef in soro woreda, hadya zone, southern Ethiopia," Journal of Natural Sciences, vol. 6, no. 19, 2016.

[19] S. Caliskan, M. Arslan, H. Arioglu, and N. Isler, "Effect of planting method and plant population on growth and yield of sesame (Sesamum indicum L.) in Mediterranean type of environment," Asian Journal of Plant Sciences, vol. 3, no. 5, pp. 610-613, 2004.
[20] R. Leta, "Effects of sowing method and inorganic fertilizer type on yield and yield components of tef [Eragrostis tef (zucc.) Trotter] at Guduru Woreda, Western Oromia, Ethiopia," M.Sc. Thesis, Haramaya University, Haramaya, Ethiopia, 2012.

[21] U. A. Soomro, M. U. Rahman, E. A. Odhano, S. Gul, and A. Q. Tareen, "Effects of sowing method and seed rate on growth and yield of wheat (Triticuma estivum)," World Journal of Agricultural Sciences, vol. 5, no. 2, pp. 159-162, 2009.

[22] S. Tolosa, "Effects of sowing method and inorganic fertilizer type on yield and yield components of tef [Eragrostis tef (Zucc.) Trotter] at A'ada Woreda, Central Ethiopia," M.Sc. Thesis, Haramaya University, Haramaya, Ethiopia, 2012.

[23] M. Farooq, M. A. Shahzad, A. S. Basra, and A. S. Basharat, "Direct seeding method popular among rice farmers, DAWN Group of News letter," Sri Lanka, vol. 89, no. 2, pp. 11-28, 2006.

[24] U. A. Soomro, M. U. Rahman, E. A. Odhano, S. Gul, and A. Q. Tareen, "Effects of sowing method and seed rate on growth and yield of wheat (Triticuma estivum)," World Journal of Agricultural Sciences, vol. 5, no. 2, pp. 159-162, 2009.

[25] J. Mazurek and A. Sabat, "Effect of sowing rate and nitrogen fertilizer application on yields of some triticale cultivars," Pamie Hook tnikPulawski, vol. 83, pp. 85-93, 1984.

[26] L. Zeng and M. C. Shannon, "Effects of salinity on grain yield and yield components of rice at different seeding densities," Agronomy Journal, vol. 92, no. 3, pp. 418-423, 2000.

[27] A. Z. Salilew, "Effects of nitrogen, phosphorus and farmyard manure on growth, yield and nutrient uptake of triticale (X triticosecale wittmack) in south gondar zone, Ethiopia," MSc. Thesis, p. 98, Haramaya University, Haramaya, Ethiopia, 2007.

[28] H. Fufa, B. Efrem, and H. Tefera, "Interrelationships of grain yield, lodging and agronomic traits in tef, Eragrostis tef," Tropical Science, vol. 39, pp. 63-69, 1999. 